\title{
Deoxyribonucleic Acid Homologies of Lactobacillus jensenii, Lactobacillus leichmannii, and Lactobacillus acidophilus
}

\author{
FRANCIS GASSER AND MONIQUE JANVIER \\ Unité de Physiologie Cellulaire, Département de Biochimie et Génétique Microbienne, Institut Pasteur, \\ 75124 Paris, France
}

\begin{abstract}
Labeled $\left[{ }^{3} \mathrm{H}\right]$ deoxyribonucleic acid (DNA) from Lactobacillus jensenii ATCC 25258 yielded a substantial amount of heteroduplexes only with DNA molecules from other strains of $L$. jensenii. A low yield of heteroduplexing was obtained between DNAs of $L$. jensenii and $L$. acidophilus, although both species had the same guanine plus cytosine content $(36 \mathrm{~mol} \%)$. The striking phenotypic similarity between $L$. jensenii and $L$. leichmannii was not reflected in their DNA base composition (36 and $50 \mathrm{~mol} \%$ guanine plus cytosine, respectively), and, as expected, they produced a very low yield of hybridized DNAs. Although the phylogenic relationship between these different species of Lactobacillus cannot be deduced from their DNA relatedness, it can nevertheless be established from the structural similarity of their D-lactic dehydrogenases.
\end{abstract}

Lactobacillus jensenii possesses all of the usual phenotypic characters commonly assigned to Lactobacillus leichmannii (4). These two species were at first distinguished solely on the basis of their D-lactic dehydrogenases (D-LDH) complement and on the electrophoretic mobility of these enzymes (5). The guanine plus cytosine $(\mathrm{G}+\mathrm{C})$ content of their deoxyribonucleic acid (DNA), $50.8 \mathrm{~mol} \%$ for L. leichmannii and 36.1 $\mathrm{mol} \%$ for $L$. jensenii, confirmed the existence of two distinct species among the strains previously confused in a single nomenspecies, $L$. leichmannii.

$L$. acidophilus and $L$. jensenii have an equivalent $\mathrm{G}+\mathrm{C}$ ratio: $36 \mathrm{~mol} \%$. However, these two species can be distinguished mainly on the basis of the hydrolysis of arginine by $L$. jensenii and the fermentation of lactose by $L$. acidophilus. Moreover, L. acidophilus produces DL-lactic acid with two distinct stereospecific nicotinamide adenine dinucleotide (NAD)-dependent LDHs, whereas $L$. jensenii produces only D(-)-lactic acid with one D-LDH only.

Antisera prepared against pure NAD-dependent D-LDHs of $L$. leichmannii and of $L$. jensenii were used for an extensive comparison of these isofunctional enzymes in the genus Lactobacillus (6). The order of decreasing similarity of all these cross-reacting enzymes established by the Ouchterlony method with $L$. leichmannii and $L$. jensenii D-LDHs taken as immunological reference points showed that there was a close structural similarity between the D-LDHs of $L$. acidophilus, L. jensenii, and $L$. leichmannii. This result was confirmed by quantitative microcomplement fixation.
To investigate further the relatedness between $L$. acidophilus, $L$. leichmannii, and $L$. jensenii, we performed DNA-DNA hybridization between representative strains of these three species.

\section{MATERIALS AND METHODS}

Bacterial strains. The bacterial strains used in this study are listed in Table 1. Details on these strains were presented previously $(4,5)$. Cells were grown at $37^{\circ} \mathrm{C}$ in De Man, Rogosa, and Sharpe (MRS) medium (3) in a Biolafitte 2-liter fermentor with the $\mathrm{pH}$ maintained at 5.8 by the addition of sodium hydroxide monitored by a glass electrode. Cells were harvested during the early stationary phase by centrifugation, washed twice in tris(hydroxymethyl)aminomethane-hydrochloride buffer [ $50 \mathrm{mM}$ (hydroxy-methyl) aminomethane adjusted to $\mathrm{pH} 8$ with $\mathrm{HCl}]$, and stored at $-20^{\circ} \mathrm{C}$ before use.

Methods. Tritium-labeled DNA from $L$. jensenii ATCC 25258 and $L$. acidophilus $63 \mathrm{E}$ was obtained from cells grown at $37^{\circ} \mathrm{C}$ without $\mathrm{pH}$ regulation in MRS medium supplemented with $20 \mu \mathrm{Ci}$ of $\left[{ }^{3} \mathrm{H}\right]$ thymidine per $\mathrm{ml}\left(\left[\right.\right.$ methyl $\left.^{3} \mathrm{H}\right]$ thymidine with a specific activity of $1 \mathrm{Ci} / \mathrm{mmol}$, purchased from Commissariat à l'Energie Atomique, France).

The methods of DNA extraction, purification, and hybridization used in this study were previously published in detail (7). The specific radioactivity of ${ }^{3} \mathrm{H}$ labeled DNA obtained from $L$. jensenii was 120,000 $\mathrm{cpm} / \mu \mathrm{g}$, and that from $L$. acidophilus $63 \mathrm{E}$ was 128,000 $\mathrm{cpm} / \mu \mathrm{g}$.

\section{RESULTS AND DISCUSSION}

The results of the hybridization experiments are summarized in Table 1. In the DNA-DNA homologous reactions there was 89 to $96 \%$ reassociation with $L$. jensenii ATCC 25258 and 91 to $94 \%$ with $L$. acidophilus $63 \mathrm{E}$. 
TABLE 1. Percentage of hybridization of DNAs from L. jensenii ATCC 25258 and L. acidophilus $63 E$

\begin{tabular}{|c|c|c|c|}
\hline \multirow{2}{*}{ Strain } & \multirow{2}{*}{$\mathrm{G}+\mathrm{C}$ content $(\mathrm{mol} \%)$} & \multicolumn{2}{|c|}{ DNA-DNA hybridization (\%) of ["H]DNA from: } \\
\hline & & L. jensenii ATCC 25258 & L. acidophilus $63 \mathrm{E}$ \\
\hline \multicolumn{4}{|l|}{ L. jensenii } \\
\hline ATCC 25258 & \multirow{7}{*}{$36.1(4)^{a}$} & 100 & 10 \\
\hline $60 \mathrm{E}$ & & 103 & \\
\hline $63 \mathrm{AN}$ & & 101 & 16 \\
\hline $66 \mathrm{~A}$ & & 93 & \\
\hline $62 \mathrm{~F}$ & & 103 & 12 \\
\hline $63 \mathrm{AA}$ & & 102 & 20 \\
\hline $63 \mathrm{~A}$ & & 64 & \\
\hline \multicolumn{4}{|l|}{ L. acidophilus } \\
\hline \multicolumn{4}{|l|}{ Group I: } \\
\hline $63 \mathrm{E}^{b}$ & \multirow{4}{*}{$36.6(6)$} & 18 & 100 \\
\hline NCD03 & & 20 & 67 \\
\hline $65 \mathrm{~K}$ & & 18 & 67 \\
\hline A20 & & 18 & 89 \\
\hline \multicolumn{4}{|l|}{ Group II: } \\
\hline $\mathrm{A} 5^{b}$ & \multirow{2}{*}{$38.1(6)$} & 12 & \multirow[t]{2}{*}{14} \\
\hline A11 & & 14 & \\
\hline \multicolumn{4}{|l|}{ Group III: } \\
\hline NCD01 & \multirow{2}{*}{$35.7(6)$} & 14 & \multirow[t]{2}{*}{20} \\
\hline A18 & & 17 & \\
\hline \multicolumn{4}{|l|}{ L. leichmannii } \\
\hline ATCC 4797 & \multirow[t]{2}{*}{$50.8(6)$} & 23 & \multirow[b]{2}{*}{13} \\
\hline ATCC 7830 & & & \\
\hline
\end{tabular}

"Numbers in parentheses are reference numbers.

${ }^{b}$ Groups I, II, and III of $L$. acidophilus refer to the immunological character of both their D- and L-LDH (6).

The labeled DNA of $L$. jensenii ATCC 25258 gave high levels of hybridization only with the DNAs of the strains of $L$. jensenii tested, showing that all these strains belong to a single genospecies. On this basis, $L$. jensenii is a genospecies clearly distinct from $L$. acidophilus, a species with an equivalent $\mathrm{G}+\mathrm{C}$ content: there is a low yield of heteroduplexes between the DNAs of $L$. jensenii and $L$. acidophilus regardless of the reference DNA.

The distinction between $L$. jensenii and $L$. leichmanii cannot be easily deduced from the common phenotypic characters used in Lactobacillus identification: growth temperature, nutritional requirements, arginine hydrolysis, and substrate fermentation produce identical results with both species (4). Lactose is fermented slowly by some strains of $L$. leichmannii and not at all by strains of $L$. jensenii. The fermentation of ribose by $L$. jensenii observed by Carlsson and Gothefors (2) could not be confirmed with our strains. However, the $\mathrm{G}+\mathrm{C}$ contents of the DNAs of these two species are greatly different, and thus, as expected, the yield of heteroduplexes between their DNAs is very low.

As previously observed in the genus Leucon. ostoc (7), there is good correlation between groups of strains with high DNA-DNA homologies and groups with close immunological similarities of isofunctional enzymes. The three distinct genospecies $L$. leichmannii, $L$. jensenii, and $L$. acidophilus produce D-LDHs belonging to different immunological groups. On the basis of both D- and L-LDH enzymes considered separately, $L$. acidophilus was divided into three different immunological groups: I, II, and III (6). Our experiments with $\left[{ }^{3} \mathrm{H}\right] \mathrm{DNA}$ from strain 63 E from group I show that only the DNAs from the strains of this group produce a substantial yield of hybridization. This observation suggests that the correlation between genospecies and immunological group already noted in Leuconostoc might also apply to $L$. acidophilus.

The respective $G+C$ contents of $L$. leichmannii $(50 \mathrm{~mol} \%)$ and of $L$. jensenii and L. acidophilus (36 mol\%) reflect a drastic change in their genome composition during the course of evolution from a common ancestor. However, the gene coding for D-LDH was probably not submitted to such an important change. The indexes of dissimilarity shown in Table 2 for the D-LDH of the three species considered indicate (according to Arnheim et al. [1] and to Prager et al. [9]) that the number of amino acid changes in 
the protein sequence is not greater than 1 or 2 . This close phylogenetic relatedness revealed by enzyme immunology cannot be shown by DNA comparison studies of the whole genome. The product of some genes can then be used as long distance markers to establish the links between genospecies or even taxa of higher rank (8).

TABLE 2. $G+C$ content and indexes of dissimilarity of $D$-LDH obtained through microcomplement fixation of three species of Lactobacillus (6)

\begin{tabular}{lcc}
\hline \multicolumn{1}{c}{ Species } & $\mathrm{G}+\mathrm{C}$ content (mol\%) & $\begin{array}{c}\text { Indexes of dissimi- } \\
\text { larity of their D- } \\
\text { LDH }^{a}\end{array}$ \\
\hline $\begin{array}{l}\text { L. leichmannii } \\
\begin{array}{l}\text { L. jensenii } \\
\text { L. acidophilus } \\
\text { I, II, III }\end{array}\end{array}$ & 50 & 1 \\
\hline
\end{tabular}

${ }^{a}$ These indexes of dissimilarity were obtained with an antiserum, anti-D-LDH of $L$. leichmannii.

\section{ACKNOWLEDGMENT}

This work was supported by research funds of the University Paris VII.

\section{REPRINT REQUESTS}

Address reprint requests to: Dr. Francis Gasser, Unité de Physiologie Cellulaire, Départment de Biochemie et Génétique Microbienne, Institut Pasteur, 75015 Paris, France.

\section{LITERATURE CITED}

1. Arnheim, N. E., E. M. Prager, and A. C. Wilson. 1969. Immunological prediction of sequence differences among proteins. J. Biol. Chem. 244:2085-2094.

2. Carlsson J., and L. Gothefors. 1975. Transmission of Lactobacillus jensenii and Lactobacillus acidophilus from mother to child at the time of delivery. J. Clin. Microbiol. 1:124-128.

3. De Man, J. C., M. Rogosa, and M. E. Sharpe. 1960. A medium for the cultivation of lactobacilli. J. Appl. Microbiol. 23:130-135.

4. Gasser, F., M. Mandel, and M. Rogosa. 1970. Lactobacillus jensenii sp. nov., a new representative of the subgenus Thermobacterium. J. Gen. Microbiol. 62:219222.

5. Gasser, F. 1970. Electrophoretic characterization of lactic dehydrogenases in the genus Lactobacillus. J. Gen. Microbiol. 62:223-239.

6. Gasser, F., and C. Gasser. 1971. Immunological relationships among lactic dehydrogenases in the genera Lactobacillus and Leuconostoc. J. Bacteriol. 106:113125.

7. Hontebeyrie, M., and F. Gasser. 1977. Deoxyribonucleic acid homologies in the genus Leuconostoc. Int. J. Syst. Bacteriol. 27:9-14.

8. London, J., and K. Kline. 1973. Aldolase of lactic acid bacteria: A case history in the use of an enzyme as an evolutionary marker. Bacteriol. Rev. 37:453-478.

9. Prager, E. M., and A. C. Wilson. 1971. The dependence of immunological cross-reactivity upon sequence resemblance among lysozymes. J. Biol. Chem. 246:5978-5989. 